\title{
Projects for intelligent and smart cities: technology and innovation transforming city ecosystems
}

\author{
Komninos, Nicos ${ }^{1 *}$, Tsampoulatidis, Ioannis ${ }^{2}$, Kakderi, Christina ${ }^{1}$, Nikolopoulos, Spiros ${ }^{2}$, \\ Kompatsiaris, Ioannis ${ }^{2}$ \\ ${ }^{1}$ URENIO Research, Aristotle University, ${ }^{2}$ Centre for Research \& Technology Hellas
}

\begin{abstract}
Intelligent cities or smart cities evolve bottom-up along with the digitisation and the creation of digital entities linked to human activities, physical space, and institutional settings of cities; but also, they progress top-down through smart city strategies and projects designed and implemented by public authorities. Yet, thirty-five years since the first use of the term "smart city" or "intelligent city" in the second half of the 1980s, and more than ten years of intense publications in this field, since 2009, there is still a great deal of fuzziness about the projects that make cities intelligent or smart. There is low awareness about the big differences between large, complex urban projects, such as 'Zero Energy Districts' or "Mobility-as-a-Service" and projects for automation of city infrastructures, such as smart city lighting, smart metering or finding a parking place. There is a widespread misconception that city intelligence or smartness, the core attribute of smart cities, can be achieved through automation of the city infrastructure.

This paper focuses on projects that make cities intelligent or smart. Our intention is to show the complexity and effort needed to achieve this objective. It is an inquiry on projects and data from a large number of smart cities around the world. We analyse core properties of smart city projects, such as (a) interventions on the physical, social, and digital space of cities, (b) the relation to city sectors and ecosystems, (c) engagement of users and stakeholders in decision-making, and (c) impact through optimisation and innovation of city processes and routines. We discuss also projects we have designed and implemented in the framework of URENIO Research and ITI-CERTH. Our conclusions are twofold. First, we propose a typology of smart city projects along 3 axes and 9 properties. Second, we argue that success and failure to achieve city smartness are mainly institutional. Most barriers to implementation are organisational, legal, and institutional. This can be explained by the social and institutional inertia of the urban system against new solutions, especially when innovation and radical change of existing routines take place. Change management should be a permanent companion of smart city projects implementation, and the modification of routines should be clearly defined and considered already at the design phase of projects.
\end{abstract}

\section{Introduction}

Intelligent cities or smart cities* evolve bottom-up along with the digitisation and the creation of digital entities linked to human, physical, and institutional elements of cities; but also, they progress top-down through smart city strategies and projects designed and implemented by public authorities. Yet, thirtyfive years since the first use of the term "smart city" or "intelligent city" in the second half of the 1980s (Komninos and Mora, 2018), and more than ten years of intense publications in this field, since 2009, there is still a great deal of fuzziness about the projects that make cities intelligent or smart. There is low awareness about the big differences between large, complex urban projects, such as the 'Positive Energy Districts', and city infrastructures automation projects, such as smart city lighting or smart metering. There is a widespread misconception that city intelligence or smartness, the core attribute of smart cities can be achieved through automation of the city infrastructure.

\footnotetext{
* Corresponding author

** The terms "intelligent city" and "smart city" describe the same transformation of cities with digital technologies, though there are some differences in the technologies used (platforms vs. IoT) and impact (empowerment vs. automation). Hereafter, we use the terms alternately as denoting the same phenomena.
} 
This paper focuses on projects that make cities intelligent or smart. As W. Michell has put it "our cities are fast transforming into artificial ecosystems of interconnected, interdependent intelligent digital organisms" (Michell, cited by Kogal and Lee, 2014). It is an inquiry on projects that contribute to the making of city intelligence or city smartness. As a point of departure, we take the statement that a "smart city project" is a project that has an impact in supporting a city to become a smart city. Smart city projects are multi-dimensional, actively engaging citizens and other stakeholders, use innovative approaches and integrate multiple digital and non-digital components of cities (Bosch et al., 2017). Besides their importance, there is limited literature on their variety, typology, success and failure factors.

Kogan and Lee (2014) for instance, argue that the most important variable that determines the success of a smart city project is not the digital technology or smart equipment but the level of citizens engagement. Van Winden et al. (2016), having studied 12 smart city projects in the city of Amsterdam, argue that success comes along with rollout, expansion, and replication. These are forms of upscaling pilot experiments and small demo projects. In roll-out, the technology or solution that was successfully tested and developed in the pilot project is commercialised/brought to the market (market roll-out); expansion takes place by adding partners, extending the geographical area covered by the solution, or adding functionality; in replication, the pilot solution is replicated elsewhere, in another organisation, city district or another city. In other studies, smart city projects have been considered within their context and interests (eventually conflicting) of stakeholders and city organisations. Success and failure come from a collective learning procedure, in which digital technologies, data and analytics, interact with background processes, the local history, and dynamics of cities (Tran Thi Hoang et al., 2019).

In this paper, we focus on the making of city smartness, the projects that contribute to this objective. Our hypothesis is that success and failure to achieve city smartness is mainly institutional. We argue that smart cities are networked cyber-physical-social spaces with strong connections between human, digital systems, communities and institutions, which enhance learning, innovation, and optimisation. Smart city projects enable such systems to form and operate better. Their failure relates to factors that constrain a long-term and stable integration between humans, organisations, and machines. To assess this hypothesis, we analyse the core properties of smart city projects, such as (a) interventions on the physical, social, and digital space of cities, (b) relation to city sectors and ecosystems, (c) engagement of users and stakeholders in decision-making, and (c) impact through optimisation and innovation of city processes and routines. We discuss the significance of these properties, and present evidence on the success and failure of smart city projects we have developed over the last twenty years.

The structure of the paper is very straightforward. Following this introduction and problem statement, section two refers to the literature on the making of city smartness. We discuss the theoretical framework of the intelligent/smart city as a new urban paradigm enabling processes of digital transformation, optimisation, and innovation; the supply chain of the smart city; and the relation between strategic planning and projects that make cities smart. Then, in section three, we look into empirical data coming from a large number of smart cities around the world. We analyse the projects implemented in these cities, their typology, cyber-institutional-physical dimension, the city ecosystems under digital transformation; where available, we refer to impact. Section four is about success and failure factors. It is based on smart city experiments realised by URENIO Research and ITI-CERTH we have developed over a long period, mainly failures in the roll-out, expansion, and replication. The final section is about the conclusions and lessons learnt from these smart city projects in light of the literature and experiences discussed. Conclusions are about the core properties of smart city projects, integration of human, institutional, and machine capabilities, and the role of institutions in making complex adaptive ecosystems in smart cities.

\section{The making of city smartness: literature and theory framework}

Projects and planning through projects are major drivers in the creation of smart cities. Understanding their contribution, success and failure factors, demands an understanding of the fundamental entities, structure, and operation of the smart city, the supply chain for making a smart city, and the different levels of digital transformation of cities and impact. 


\section{Intelligent/smart city: a new urban paradigm}

The intelligent/smart city is a new urban development and planning paradigm. It has emerged as a disruptive approach at the convergence of (a) digital technologies and the capabilities they offer, (b) the knowledge and innovation-led development of cities, and (c) challenges of contemporary cities, such as urbanization and growth, ageing of buildings and infrastructure, traffic congestion, use of fossil energy and environmental pollution, personal safety and security, citizens' quality of life and health (Komninos, 2002; Andrisano et al., 2018; Gaffney and Robertson, 2018). In response to aspirations for urban environments without crime, cities that are safe, inclusive and innovative, cities without traffic congestion, pollution and environmental degradation, the models of sustainable urban development, represented by the "green city" and the "creative city", "smart urban growth" and other, evolved into a new paradigm, the intelligent or smart city (Greco and Bencardino, 2014).

Currently, the smart city is considered a hegemonic phenomenon in the contemporary metropolis (Rodrigues and Costa, 2020), transforming all subsystems of cities. Giffinger and Gudrun (2010) have identified six major city subsystems under transformation: smart economy, smart environment, smart governance, smart living, smart mobility, and smart people. A step further, Arroub et al. (2016) consider these dimensions as interrelated smart city paradigms creating smart economies, smart environment, smart governance, smart mobility, smart healthcare, smart living.

There is strong evidence supporting the arguments in favour of the smart city as an emerging holistic paradigm (Kunzmann, 2014; Foth, 2017; Kakderi et al., 2016). The smart city refers to a new reality, a new digital-physical-institutional architecture replacing the physical-social reality of cities (Komninos, 2014); a new set of technologies for making cities, with digital technologies added to construction technologies and management science guiding city planning (Yigitcanlar, 2016; Petrolo et al., 2017); a new way of operation of cities based on e-services, transferring activities from the physical to the digital space; new functionalities deriving from multidisciplinarity (Adrisano et al., 2018); new externalities provided over platforms and the Internet changing the way innovation is produced and diffused (Kourtit and Nijkamp 2012; Frenken and Schor, 2019; Nieuwland and Van Melik, 2020; Komninos, 2020); and most of all, new data becoming available along with e-services that transform cities into measured systems (Kourtit et al., 2017). Even critical appraisals considering the smart city as a technocratic construction made of disconnected and often incongruous pieces of the urban fabric, as an unsuccessful experiment generated by the forced union of different, incompatible elements (Cugurullo, 2018; 2021), do not deny the magnitude and disruptive character of this paradigm.

The significance of these transformations for cities is major: the theories of city organisation and growth that prevailed in the past, and the $20^{\text {th }}$ century, in particular, are not adequate to describe, explain, and forecast how cities work and evolve today under the functionalities and impact of digital technologies. The intelligent/smart city paradigm covers this gap and offers a new understanding of the dynamics of cities in the $21^{\text {st }}$ century.

A usual way to describe this new urban paradigm is through gathering and compiling concepts and definitions about what is a digital, smart or intelligent city. However, a more comprehensive understanding can be obtained by presenting the ontology of the intelligent/smart city and the major classes and properties that make this ontology.

In a recent paper (Komninos, Kakderi, and Panori, 2020) we outlined three major groups of entities within this ontology: (a) communities and subsystems, (b) knowledge and innovation processes based on data and e-services, and (c) processes of transforming both the urbanisation and city planning. These are depicted in Figure 1. At the left side is the "community hub" containing spatial, social, and digital entities organised in city subsystems and types of cyber-physical cities. On the right side is the "urbanization and planning hub", containing processes related to urbanization, challenges, environmental processes, city planning, governance, social movement, and digital system design. At the centre is the "data and e-services hub" with knowledge and innovation architectures, function, and output. From these $1^{\text {st }}$ level classes derive other entities and relationships at successive levels of detail, in total 1231 entities. The ontology makes clear that the core and driving force of the new paradigm are the "data", "e-service" and "innovation" classes, which integrated into the physical and social elements of cities disrupt all subsystems of cities. Since all subsystems of cities are affected and transformed, we have a total transformation, which justifies the view of the intelligent/smart city as a holistic city development and planning paradigm. 


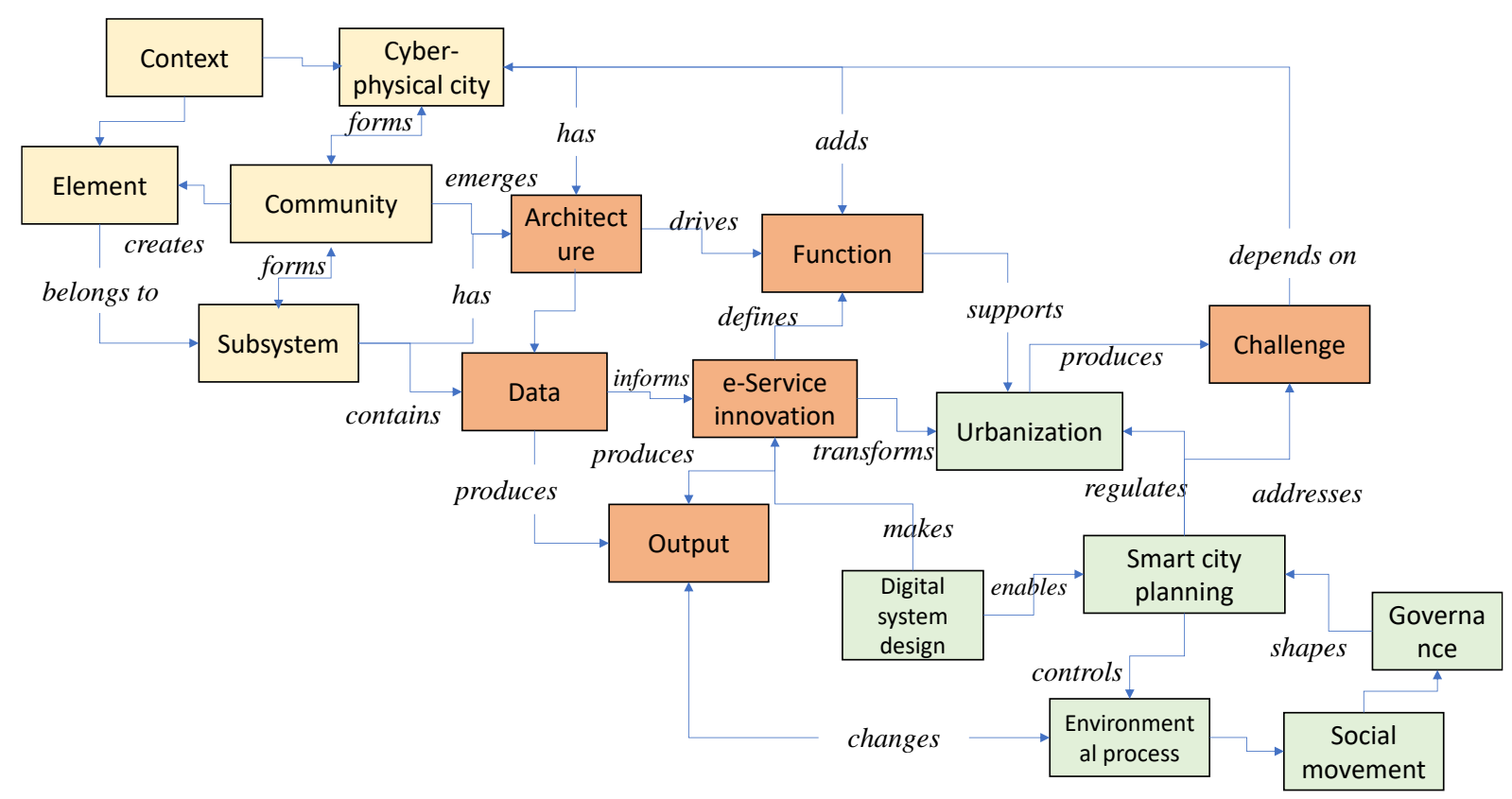

Figure 1: Intelligent/smart city ontology. First-level entities and properties Source: Komninos, Kakderi, and Panori, 2020

\section{The supply chain of the smart city}

A supply chain is the interconnection of all components and functions from the manufacturing of raw material into the finished product and ends when the product reaches the user. The supply chain is a product-based / operations-based perspective. In the case of the smart city, the supply chain includes all activities, processes and actors that contribute to the production and delivery of smart city infrastructure e-services and data. In compliance with the smart city paradigm, the supply chain and the respective production landscape is extremely wide, extends over the entire city as system-of-systems, and includes bottom-up and top-down processes, actors and contributions from many fields of science and technology.

The system-of-systems view of the smart city is widely accepted, but there is no agreement about the granularity and number of its subsystems, their typology, the number of subsystems to be transformed before a city to be considered as smart. Giffinger and Gudrun (2010) distinguish the six sub-systems in a smart city, which we have already mentioned. URENIO Research classifies smart city solutions into 5 major domains (innovation economy, living in cities, city infrastructure and utilities, city governance, generic) and 17 subdomains (https://icos.urenio.org/apps/). Frost \& Sullivan (2019) define a smart city as one that has an active plan and projects in at least five out of eight functional areas (subsystems) of energy, buildings, mobility, technology, infrastructure, healthcare, governance, and citizens. Depending on the level of granularity, a smart city may have a few or a dozen subsystems.

Bottom-up and top-down production processes are more clearly defined. Bottom-up are all marketmediated processes for the supply of products and services composing a smart city. Top-down are central and local authority actions, including, policies, regulations, plans, and projects for making a smart city.

Multidisciplinary contributions come with actors from various fields of city planning, engineering, policy and institution management, from the social sciences in the design of value networks, monitoring and assessment, as well as from a wide range of digital technologies. The description of digital technologies by Frost \& Sullivan (2019) covers a wide range of fields, such as smart grids, smart meters, broadband networks, sensor networks, digital management, e-services, in which are added sectorspecific technologies related to renewable energy, transport, health, government, and education. This is indicative of the multidisciplinary contributions and roles in the supply chain of smart cities.

The variety of subsystems, processes, actors, and technologies that contribute to the making of the smart city reveal supply chains extremely complex. They include products, services, and systems from the field of engineering, consulting, planning, integrated with information and communication 
technologies. Apart from vendors of digital products and services, the supply chain includes also suppliers offering engineering services, building technologies, construction materials, developers of city infrastructures, and multiple providers of services related to city planning and design, consulting, innovation and knowledge management, civic services, finance, standards and regulations, and many others. This landscape is by far wider than the landscape of digital technologies and broadband services. The smart city is not a digital city only, but a full flesh physical, social, and digital system. Rules and regulation institutions are equally important to digital technology. The same goes for context and skills. The city and the smart city are not objects, but complex systems emerging from a million individual actions of citizens and producers, which city planning attempts to coordinate and give coherence.

\section{Smart city projects}

Any smart city supply chain starts with digital entities. It may be a digital infrastructure, a smart object, a dataset, an application, an e-service. The report of ITU-T Focus Group on Smart Sustainable Cities (ITU-T FG-SCC, 2015) provides good technical specifications of the ICT architecture and digital elements of the smart city. From bottom to top the proposed architecture is structured in four layers:

- the sensing layer, including sensors, actuators, cameras, RFID readers, GPS trackers, and the connecting sensor network

- the network layer with xDSL, FTTx, WiFi, metro network, $2 \mathrm{G} / 3 \mathrm{G} / 4 \mathrm{G}$ [5G] networks

- the data and support layer, including computing and cloud computing, various databases, application support servers, and data processing services

- the application layer with multiple application for e-government, transport, healthcare, environment, safety, district and many other applications.

This architecture defines a digital system as a collection of components, each component has a specific role within the system (i.e., authentication, data repositories, etc.), while all interact to establish the entire system (ITU-T FG-SCC, 2015, p. 4).

Along any smart city supply chain, these digital elements connect to non-digital components, the physical, social, and institutional elements of cities. Each supply chain takes the form of a "project" (an individual or collaborative enterprise that is carefully planned to achieve a particular aim, according to Oxford Dictionary) for the production of a smart city infrastructure or service. Thus, "a smart city project is a project that has a significant impact in supporting a city to become a smart city [...], actively engages citizens and other stakeholders, uses innovative approaches, is integrated, combining multiple sectors" (Bosch et al. 2017, p.7)

This process of integration between digital and non-digital elements in smart city projects is reflected in the integrative framework to understand smart city initiatives, proposed by Chourabi et al. (2012). The eight components of the framework have derived from the exploration of a wide and extensive array of literature from various research fields such as e-government, local government administration and management, and information systems. The components are depicted in two circles: the internal one includes technology, organisation, and policy. The external one includes people \& communities, economy, build infrastructure, national government, and governance. Each smart city initiative or project is defined by those eight axes that compose the integrative framework.

Another multi-dimensional taxonomy of smart city projects, which also shows the integration of digital, physical, social, and institutional components, has been proposed by Perboli et al. (2014). It is based on a trend analysis of Italian and European projects, includes three axes (description, business model, and purpose), and multiple categories per axis (Table 1).

Table 1: Taxonomy of smart city projects

\begin{tabular}{|lll|}
\hline \multicolumn{1}{|c|}{ Description } & \multicolumn{1}{c|}{ Business model } & \multicolumn{1}{c|}{ Purpose } \\
\hline Objectives: & Management: & Client: \\
Governance, energy, security, etc. & Private, public, mixed & Private, public \\
Tools: & Infrastructure financing: & Product: \\
Cloud, database, legal tools, etc. & Private, public & Specific, no specific \\
Project initiator: & Financial resources: & Geographical target: \\
Public, private, mixed & Private, public & Urban, national, international \\
Stakeholders: & & \\
\hline
\end{tabular}


City, citizen, SMEs,

administrators,

\section{Source: Perboli et al., 2014}

These taxonomies show that smart city projects may be simple with a few components only (such as a dataset) or extremely complex (such as a net-zero energy district). The projects can be undertaken by any actor, person, company, non-profit organisation, community, local central state authority. Their features can be digital, physical, social, and institutional, in multiple combinations. Their context, decisive in success and failure, becomes part of their features, as technologies and tools are applied over the pre-existing physical and activity context.

Three major types of projects we can distinguish are those related to (a) information provision and creation of datasets, such as smart metering and data repositories, (b) creation of applications and eservices, such as online transactions and e-government services, and (c) more complex projects combining physical, social, and digital elements of cities, such as smart districts, smart campuses, and smart city ecosystems.

The complexity of projects has an important implication. The impact of smart city projects seems to depend on their complexity. In a previous publication (Komninos, 2016) we described the operation of smart city projects along with three circuits: c1-digital deployment; c2-optimisation / innovation at the city's production side, related to choices of private and public investments; and c3-optimisation / innovation at the city's usage side, related to the behaviour of citizens and organisations. The associated impact may be simple digitalisation, digitalisation leading to optimisation, and digitalisation leading to innovation.

Simple projects initiate digitalisation only. An activity is transferred from the physical to the digital space without any changes in its features. The case is usual in e-transactions. While a transaction becomes digital, the underlying routine (participants, objectives, model) remains the same. You can play chess over a physical table or a digital table, but the rules, logic, and tactics remain the same in both cases. When the digital deployment (c1) does not alter the related routines, the process is simple digitalisation. There is impact, but usually low.

More complex projects may initiate some form of optimisation together with digitalisation. An activity is transferred from the physical to the digital space, but together with digitalisation some feature or performance are optimised. Without changing the underlying routine, its performance may take the max or min value, depending on what is best. Automation, analytics, and guided behaviour can be optimised along with their digitalisation. This is very usual in smart solutions for mobility, energy, and utilities.

Then, high complex projects may initiate together with digitalisation radical changes in the underlying routines, introducing new operation models. This is the case for instance of Vision Zero, a combination of engineering, design, training, law enforcement and digital technologies to eliminate all traffic fatalities and severe injuries in cities, or Positive Energy Districts, which combine smart grid solutions, building refurbishment, spatial, regulatory, financial, legal, social and economic interventions towards annual net-zero energy import and net-zero $\mathrm{CO}_{2}$ emissions.

Reducing the smart city supply chain to vendors of digital technologies, services and products, is equal to reducing the impact of smart cities to digitalisation only. Defining the supply chain of smart cities by digital technologies, products and services only is accurate but extremely narrow at the same time. It only records suppliers of the digital components of smart cities. But the supply chain of smart city projects combines physical, institutional, and digital components, engages users and stakeholders in information sharing and participatory decision-making, transforms the operation model of city ecosystems, and may have a high impact through the replacement rather than optimisation of city routines.

\section{Smart city projects vs planning}

"One swallow does not make a spring". A single smart city project is not enough to change a city's subsystem, wide as the innovation economy or narrow as the water infrastructure. The system-of-system view of the smart city and the different subsystems of smart cities, six according to Giffinger and Gudrun (2010), eight according to Frost \& Sullivan (2019), dozen according to URENIO Research, 
need groups of projects to be transformed. We enter the domain of strategic planning or planning through projects (Carmona et al., 2009).

The smart city evolves from the execution of specific projects to the implementation of global strategies to tackle wider city challenges (Monzon, 2015). It is usual for a company to introduce a project, such as bike-sharing or scooter-sharing, or carpooling. Equally usual is for a local authority to make a plan and start implementing the projects designed in the plan.

Understanding the planning of intelligent/smart cities through the accumulation of digital elements, which are heterogeneous, introduced by uncoordinated and competitive actions of companies, many times experimental and incomplete, through unprecedented citizen and user engagement that may be also fragmented and diverse, is far from the usual concept of coordinated urban planning. Thus, intelligent city planning, as a control and guidance of the overall interactions between innovation circuits c1, c2 and c3, seems like "planning without a plan". It is about building smart cities more through evolution and less through detailed planning and rigid plans. It is planning under conditions of uncertainty and complexity and a rather chaotic interaction of simultaneous actions and decisions taken by many organisations each of which has its logic and plan. The outcome is more guided by market forces through opportunities that arise over time, and with the overall result being unpredictable and uncontrollable in advance.

Strategic planning through smart city projects reveals the complex character of the smart city as a synthesis of technologies, spatial and social elements, user engagement, and windows of opportunity which are fuzzy at the start of the planning process. The evolutionary features of cities, which until now were ascribed to the working of markets, are now shaping the institutional aspects of planning for smart cities (Komninos, et al., 2018). The project dimension dominates over the strategy and planning dimensions of smart cities.

\section{Smart city projects from around the world}

There are reviews on smart city plans and projects that can be used as material for meta-analysis. The latter can be performed in studies that address the same question, but the level of accuracy of each study may be questioned and the reports may have some degree of error. Meta-analysis overcomes some of the problems accounted in narrative reviews, but sources of bias remain in the selection of studies to assess and the methodologies used (Gates, 2002).

Detailed methodologies for synthesizing research using meta-analysis have developed very rapidly in medicine and health services research. Meta-analysis has also been used in ecology, education, marketing, and other fields of science. The dominant methodology for systematic reviews is based on randomized controlled trials. But some reviews have combined data from observational studies and data from qualitative research (Kulik and Kulik, 1989; Timulak, 2014; Stall-Meadows and Hyle, 2010).

We use data on smart city projects reviewed in the book "Smart City Emergence" to understand some fundamental features of these projects. As it is stated in the introduction the aim of this book is "to collect and present information from several cities around the globe with regard to their SC development. More specifically, it presents how different cities have approached the SC; the vision that they defined for their SC and the problems they wanted to solve with the corresponding smart solutions; the projects that were launched and the timeline for their development; the corresponding budgets and the implementation methodologies, etc. (Anthopoulos, 2019, p. xxi).

Following a chapter on project management, 20 city reviews are included in the book highlighting how different cities have organised their smart city process. Forty-five authors contributed to the reviews and the cities are from all the continents. While some projects and initiatives are relatively simple, others include complex efforts of articulation between the public sector, private sector, and citizens. Renovation of urban areas, intelligent lighting and traffic lights, solutions for the development of a creative economy, co-working spaces, and projects for start-ups are among them.

An overview of the cities, projects and the domain or ecosystem of reference is given in Appendix 1. Appendix 1 does not account for projects related to broadband networks, wi-fi, and open wi-fi which are offered additionally. These networks are present in all cities and together with cloud computing form the basic infrastructure on which all smart city services operate. 


\section{Structuring by ecosystems}

A very clear message from the twenty cases is about the setting of smart environments by ecosystems. The objectives of projects are either relevant to a specific ecosystem or common objectives that can be found across ecosystems. In the case study on Korea for instance, a common model for all smart cities is described, promoting an ICT-based growth of city ecosystems to sustain the innovation economy, the $4^{\text {th }}$ industrial revolution, and sandboxes for experimentation (Yong Lee and Chang, 2019). In most of the 20 cities reviewed, the authors describe projects by ecosystem or sector (energy, environment, economy, etc.). We prefer using the term ecosystem instead of sector or vertical market, which are also in use, to transfer the meaning of networking and interaction among the actors.

Table 2 shows the city ecosystems in which projects are implemented. We have identified 16 ecosystems, which are classified into three blocks, those related to (a) areas, (b) activities, and (c) networks. These three types of ecosystems have quite different locational behaviour: area-based ecosystems cluster spatially to form city districts, activity-based ecosystems spread throughout the city, and network-based ecosystems locate along the axis and transport networks. The number of ecosystems we identified is double from the number of vertical markets mentioned in the Frost \& Sullivan report (2019) and more than double from those mentioned in the grounding study by Giffinger et al. (2007).

Most frequent are projects to ecosystems related to networks and utilities (broadband, mobility, energy, etc.) (51.16\%), then follow ecosystems related to activities (economy, health, safety, etc.) $(45.35 \%)$ and a few only cities work with area-based ecosystems, such as district renewal, port and university campus renovation (3.49\%). Network optimisation seems the principal concern and objective.

The digital transformation of some ecosystems stands out as most frequently taking place in the sample of cities: governance, economy, and health in activity-based ecosystems; broadband infrastructure, mobility, and energy in network-based ecosystems. The missing cases are also significant with the absolute absence of digital transformation in areas such as the city centre, the technology districts, the housing districts, and activities such as manufacturing and culture. But maybe this is a random outcome of the sample used.

Table 2: Most common projects per typical sector or city ecosystem

\begin{tabular}{|llcc|}
\hline \multicolumn{1}{c}{ Type of ecosystem } & \multicolumn{1}{c}{ City ecosystems } & \multicolumn{2}{c|}{ Frequency in sample cities } \\
& & No of cities & $\%$ \\
\hline Area-based ecosystems & 1. District renewal-Multi-use districts & 1 & 5.88 \\
(3.49\% of all ecosystems) & 2. Hub district (port / rail / airport) & 1 & 5.88 \\
& 3. City centre & - & - \\
& 4. Technology district & - & - \\
& 5. University campus & 1 & 5.88 \\
& 6. Housing & - & - \\
& 7. Public space / natural ecosystem & - & - \\
\hline Activity-based ecosystems & 8. Governance & 11 & 64.70 \\
(45,35\% of all ecosystems) & 9. Health & 6 & 35.29 \\
& 10. Startups, innovation, skills & 5 & 29.41 \\
& 11. Safety & 5 & 29.41 \\
& 12. Living, quality of life & 5 & 29.41 \\
& 13. Education & 4 & 23.53 \\
& 14. Tourism, hospitality, shopping & 3 & 17.65 \\
& 15. Manufacturing & - & - \\
& 16. Culture, recreation & - & - \\
\hline 17. Telecom, broadband & 17 & 100.00 \\
18. Mobility & 10 & 58.82 \\
(51,16\% of all ecosystems) & 19. Energy & 8 & 47.05 \\
& 20. Environment & 4 & 23.53 \\
& 21. Water & 3 & 17.65 \\
& 22. Circular economy, recycling, waste & 2 & 11.76 \\
\hline
\end{tabular}

Source: Based on data of Appendix 1 


\section{Diversity and standardisation of projects per ecosystem}

There is high diversity of smart city projects and solutions across ecosystems. But inside each ecosystem, the diversity is low and similar projects are to be found in the same ecosystem across cities, regardless of the city geography, size, or level of prosperity. Table 3 shows the most usual projects in two ecosystems, governance and energy, in which smart systems have been had implemented in most cities examined. As we may observe, 8 projects are the most usual in both cases. Government and energy transformation takes place with these projects mainly. On the other side, comparing ecosystems, the projects are different, besides the fact that the same digital technologies of sensing, network, data and computing, and application development are used.

The significance of this observation is paramount. The same digital technologies deployed in two different ecosystems lead to totally different projects and solutions for digitalisation or optimisation. The diversity of context, actors, physical infrastructures, and social processes prevail over the homogeneity of digital technologies. The challenge for smart city projects inside each ecosystem is on the side of project design and innovation rather than on the use of technology.

Table 3: Standardisation of smart city projects per ecosystem

\begin{tabular}{|c|c|}
\hline Smart city governance projects & Smart city energy projects \\
\hline $\begin{array}{l}\text { 1. Online administrative services to citizens } \\
\text { 2. Co-design of public services }\end{array}$ & $\begin{array}{l}\text { 1. Smart metering in buildings, energy control } \\
\text { and saving }\end{array}$ \\
\hline $\begin{array}{l}\text { 3. Citizen reporting, complaints, request to } \\
\text { city administration }\end{array}$ & $\begin{array}{l}\text { 2. Energy integrated: retrofitting, PV panels, } \\
\text { RES, etc. }\end{array}$ \\
\hline 4. Citizen database and profile platform & 3. Smart grid and use of renewable energy \\
\hline 5. Open data, data sharing with citizens and & 4. District cooling and heating \\
\hline entrepreneurs & Smart public lighting \\
\hline 6. GIS data centre & Public electric vehicle charging \\
\hline 7. Digital payments & 7. Energy-related platform and transactions \\
\hline $\begin{array}{l}\text { 8. Integrated city management system, } \\
\text { command centre }\end{array}$ & $\begin{array}{l}\text { 8. Data collection, mapping, and modelling of } \\
\text { the energy system }\end{array}$ \\
\hline
\end{tabular}

Source: Based on data of Appendix 1

\section{Projects and technology}

However, the role of technology is not neutral. The technology used is particular to the ecosystem and features of projects. This becomes evident by comparing the survey on the 20 cities included in the book Smart City Emergence with another survey on IoT-based smart city use cases. IoT Analytics (2020) realised a survey in 50 city decision-makers from the world's leading Smart City initiatives and classified the smart city vendors in 6 categories of products and services providers, offering (1) sensor and end-devices, (2) network equipment and infrastructure, (3) connectivity and network-related services, (4) edge/core compute hardware and software, (5) software platforms and apps, and (6) professional services. Table 4 shows the top smart city use cases concerning IoT and the above vendors. As should be expected, projects for mobility, environment, energy and building infrastructure are most usual, because in these domains the deployment of IoT and sensors mostly takes place. Uses cases related to governance, the economy or heath do not figure in the list of top smart city solutions as IoT solutions are less relevant in these domains.

Table 4: Top 10 smart city IoT-based use cases

\begin{tabular}{|llcl|}
\hline Rank & \multicolumn{1}{c|}{ Use case } & Share & \multicolumn{1}{c|}{ Sector or Ecosystem } \\
\hline 1 & Connected public transport & $74 \%$ & Mobility and transportation \\
2 & Traffic monitoring and management & $72 \%$ & Mobility and transportation \\
\hline 3 & Water level / flood monitoring & $72 \%$ & Environment \\
6 & Weather monitoring & $68 \%$ & Environment \\
7 & Air quality / pollution monitoring & $68 \%$ & Environment \\
10 & Water quality monitoring & $64 \%$ & Environment \\
\hline 5 & Connected streetlights & $68 \%$ & Energy and utilities
\end{tabular}




\begin{tabular}{|llll|}
8 & Smart metering - Water & $66 \%$ & Energy and utilities \\
\hline 4 & Video surveillance and analytics & $72 \%$ & Public safety \\
\hline 9 & Fire / smoke detection & $66 \%$ & Building and infrastructures \\
\hline \multicolumn{4}{r}{ Source: IoT analytics, cited by Wray (2020) } \\
\hline
\end{tabular}

\section{Typology of projects and architectures of integration}

We classified the projects of Appendix 1 in the three categories we mentioned in section 2: (a) projects developing digital applications and e-services, (b) projects for data repositories, monitoring, metering, and analytics, and (c) cyber-physical projects with interventions on both the digital and physical space of cities. The allocation of projects in these three categories appears in Table 5 with close shares between e-services and cyber-physical projects. The case for data creation, monitoring and analytics are less frequent.

Table 5: Allocation of smart city projects per types

\begin{tabular}{|c|c|c|c|}
\hline $\begin{array}{c}\text { Projects for smart city e- } \\
\text { services }\end{array}$ & $\begin{array}{c}\text { Projects for data creation } \\
\text { monitoring, analytics }\end{array}$ & Cyber-physical projects & Total \\
\hline 96 & 28 & 82 & 206 \\
\hline $46.06 \%$ & $13.59 \%$ & $39.81 \%$ & $100 \%$ \\
\hline
\end{tabular}

Project types follow the ecosystem: in ecosystems related to economy, government, education, and health prevail the creation of applications, platforms, and e-services. Cyber-physical systems and IoT solutions prevail in ecosystems related to mobility, energy, and the environment. Projects for data creation, monitoring and analytics are found in all ecosystems. However, there is no exclusion, and all types of projects are deployed for the digital transformation of city ecosystems.

Within each ecosystem, smart city projects agglomerate. Each is placed by the other but lacks connectivity and integration. We have called this architecture "agglomeration of digital applications and solutions" and marks the lower level of spatial intelligence that can be found in smart cities (Komninos, 2018). It is usual at the starting phase of smart cities in the same way that the spatial agglomeration of activities is the starting phase at the beginning of urbanization.

More integrated architectures are found in the domain of energy where a combination of smart grid, renewable energy production, building refurbishment, smart home solutions, and smart metering and projects work together and form a system of smart energy. Smart campuses and smart district show also similar architectures of integration. But their presence in cities is rather limited.

Overall standalone projects prevail over more complex and integrated ones. This is probably a trait of low maturity at the initial stage of smart city development.

\section{Drivers and barriers: Lessons from smart city projects of URENIO and ITI- CERTH}

During the last twenty years URENIO Research, a lab of the Aristotle University of Thessaloniki, and the Informatics and Telematics Institute of the Centre for Research and Technology Hellas (ITICERTH) developed and experimented with a series of solutions for smart cities, which allow identifying drivers and barriers in the deployment of smart city projects. Here, we refer to three projects that reveal three major driver conditions in shaping such projects, and barriers due to the institutional inertia of the urban system.

\section{Improve-my-City: collective intelligence and reward for engagement}

The application and the respective e-service is a direct citizen-government communication and collaboration. It is available through the web (https://www.improve-my-city.com/) and smartphones, android and iPhone. The service enables citizens to report non-emergency problems and the government to respond to their requests, provide solutions, and feedback to users. The requests submitted to local authorities are displayed on the city map and are accompanied by comments, pictures or video, and suggestions for solution. Citizen requests are classified into categories defined by the city administration and each request is transferred to the department responsible, which takes action to address it. 
Additionally, the backend of the application provides analytics to aggregate and visualise data, identify areas where problems are most frequently reported, and the performance of the city's administrative departments (Komninos, 2020). ImproveMyCity (IMC) promotes participatory government of local communities and acts as an instrument for the engagement of citizens in the management of cities.

IMC is an application and e-service in the field of social innovation. These innovations do not conform to the dominant concept of innovation as new product and business development but are innovations social both in their ends, servicing social objectives, and in their means, based on collective action (Caulier-Grice, 2016). Besides the exponential growth of social innovations over the last years, there is no commonly accepted definition of what is social innovation. There are numerous definitions, with little consensus and much debate.

IMC serves collective objectives, as citizens report issues of the public space of cities to improve the city as a space of public goods and commons, and introduces a bottom-up participatory government - more direct than representative decision-making - in which citizens direct and prioritise public action.

IMC is an open-source scalable software solution, initially launched in 2012, in the context of the EU's 'PEOPLE' research project (EU-CIP). The PEOPLE project included a series of experiments in social innovation at the level of smart city districts in four pilot urban areas: the cultural district of Bilbao (Spain), the university campus and technology park of Bremen (Germany), the central commercial district of Thermi, a city within the metropolitan area of Thessaloniki (Greece), and the housing district of Vitry-sur-Seine, a suburb of Paris (France). The first version of IMC was developed by URENIO Research. Then, ITI-CERTH developed the smartphone versions.

The service was initially provided by the city of Thermi to enable those who live, work or visit the city to report local problems such as discarded garbage, burned light bulbs, broken pavement tiles, illegal billboards, illegally parked vehicles, etc. Citizens made suggestions for improving the city's infrastructure, but also commented and voted in favour of existing registrations.

On a larger scale, the service was introduced by the city of Thessaloniki to manage the daily problems of the citizen, providing a platform for submitting, managing and analyzing his requests. The submission of requests is done under clear terms related to the pilot operation of the service, the submission of requests in predefined categories, the posting of non-emergency requests, the posting of content that is not untrue, defamatory, inaccurate, aggressive, offensive, threatening, threatening to the privacy of a person, entries are personal views and experiences of their authors, the administrators of the service do not guarantee the accuracy of the information published and retain the right to delete inappropriate content, requests are free, but the user remains solely responsible and accountable for the content of the entries.

To date, more than 60,000 requests have been submitted in Thessaloniki and 3,000 in Thermi, which is a much smaller community. The application is multilingual and is already used in other 30 cities across Europe, the US, Mexico, Brazil, Angola, Indonesia, India, and Russia. The two municipalities, Thessaloniki and Thermi were awarded for the implementation of Improve-my-City by the Council of Europe at the inaugural event of the "European Badge of Excellence in Good Governance" Programme. The success of this type of e-service can be attributed to several factors:

- IMC includes a recommendation/reward system in which citizens raise demands and suggestions and the public authority respond to these demands.

- IMC is interactive and provides a solution that incorporates best practice towards better user experience such as keyboard-friendly interfaces and offline use of mobile devices.

- IMC offers analytics documenting fields of citizen concern, weaknesses of the urban system, as well as the performance of the public authority to respond to these demands.

- IMC relies heavily on principles of openness and transparency, which we found to be fundamental for the smooth operation and adoption of smart city services. Municipalities that try to limit transparency by displaying to users only their submitted issues and not showing issues reported by other citizens have a negative impact and should be discouraged (Tsampoulatidis et al., 2020).

All-in-all, Improve-my-City is a smart city service that introduces an innovation in the mainstream city top-down administration, offers a platform to be adapted to challenges of each community, works as crowdsourcing aggregators of citizen requests and ideas, rewards the citizen for the engagement, and promotes collective intelligence in setting priorities for city planning and management. 


\section{CUTLER's smart parking: new e-services over data}

The Municipality of Thessaloniki is a densely inhabited area and many of its districts are not strictly residential but also include professional spaces, hotels, shops, entertainment areas, hospitals, and others. As a result, people move to or out of these areas during the whole day, creating a high demand for public parking space. Since both residents and visitors must be served, the available parking space needs to be controlled and allocated. Since November 2017, a new controlled smart parking system has been introduced in three municipal departments and the available parking space has been divided into white and blue sectors, destined for the parking needs of visitors and permanent residents, respectively. Visitors pay a fee to park their vehicle in white sectors. Residents are holders of parking cards that allow them to park their vehicles in any spot of a blue sector of their district. The system is supervised by the Municipal Police that performs daily patrols in the city streets, scanning car plates and issuing tickets in case of illegal parking by either visitors or residents. The need to optimize the Controlled Parking System (CPS) of Thessaloniki has motivated the development of tools to improve the following aspects.

Optimal allocation of parking sectors: When the CPS started operating in November 2017, an initial allocation of residents' and visitors' sectors was decided. The main criterion for this decision was land use, thus more white (visitors') sectors were assigned to streets close to shops while more blue (residents') sectors were assigned to streets around residential blocks. Moving from decision-making through intuition to decision-making based on evidence, the Municipality of Thessaloniki have decided to rely on the CUTLER platform to decide on the optimal allocation of white and blue sectors based on the following data: GIS data on land use, census data on population and number of cars per block, environmental data on air pollutants and traffic emissions, social data on citizens' complaints on the existing allocation of on-street parking space and, finally, data on revenues of the system and the legal or illegal behaviour of the CPS users from the date the CPS began operating till the date of a new intervention on the system. By resolving the parking problem and the traffic generated by the parking problem, the expectation has been to decrease air pollution in the city centre, improve quality of life for both residents and visitors, and increase the municipality's revenues from visitor tickets. In this context, the goal was to examine the problem of optimally allocating the public parking space to city centre residents and visitors (white \& blue sectors), considering economic, social and environmental aspects.

Optimized patrol routes: Every day, based on the available municipal police force, patrols in pairs are organized to monitor the CPS. The CUTLER platform was customized for suggesting patrol routes to cover as many CPS sectors as possible and thus reducing illegal parking. The decision-maker can set a maximum number of kilometres that a pair of policemen can walk during their shift, while the recommended patrol routes are of similar distances so that all available personnel is treated in an equal manner. The aim is to handle the available workforce most efficiently to save work hours that can be assigned to other tasks. After deciding on the patrol routes, the decision-maker can monitor the effect of this decision on the CPS (revenues, legal and illegal scans, etc.) and finally evaluate this decision based on parking-related and social KPIs. In this process, our goal was to examine specifically the design of optimal patrol routes to supervise the CPS and reduce illegal parking, considering economic, social, and environmental aspects.

The aforementioned technical solutions have been decided and designed in collaboration with the policymakers of the Municipal Police and enjoyed their full support during their implementation. Nevertheless, they were confronted with several barriers hindering their fully successful implementation. These include:

Data exists but is not always readily available: During the last few years, the volume and diversity of the data generated daily in cities by citizens, businesses, and the public administration has significantly increased. However, public administrations still struggle to fully exploit this data to improve governmental processes. One of the main reasons is that although the data is out there, most of the time public administration stakeholders cannot access it. This may be due to data belonging to or managed by private organisations, civil society organisations, or other government departments of the same organisation. It is thus necessary for the municipalities to open a communication channel that will allow them to negotiate and cooperate with new partners to gain access to information that can greatly enrich urban planning and dialogue. This has been the case for a significant amount of CPS-related data that were hosted by a private company. Despite the existence of a contract stating that the data generated through the CPS system is a property of the municipality, it has proved extremely difficult to obtain the necessary amount of data at the necessary level of granularity. 
Legal issues hinder data collection \& processing: Legal issues involved in acquiring and processing the available data, especially in the case of data owned by third parties and sensitive/personal data. Different datasets adhere to different sets of rules and regulations, thus, making it extremely difficult for the data processors in public administration to know how to handle them. This has been particularly relevant in the case of the CPS, since data like car plates, GPS location of cars and penalty notices should be treated as sensitive data, requesting strong anonymisation measures. To this end, it is important to have a robust legal framework that will enable policymakers to handle such issues in a standardized way.

Change management for key stakeholders to move away from intuition-based decision making: Despite the success of the aforementioned technical solutions to collect the necessary sources of data, insightfully present them and extract the necessary pieces of evidence, we were frequently confronted with a situation where it was impossible to convince some of the key stakeholders in trusting the system and accepting suggestions that were not aligned with their intuition. Building an accurate system is as important as convincing its end users to put trust in it, and their early involvement in the design phase is an effective way to achieve the necessary change management.

External factors can always become the reason for cancelling out a certain solution: Even in the cases where everything works as expected a smart city solution may still be confronted with a situation where socio-cultural or political reasons renders its value minimal. This has been the case for the application of the CPS in Municipal Departments outside the city centre, where the opposition of permanent residents against the controlled parking system has forced the authorities to revoke its application.

\section{STORM Cloudfunding: organisational and institutional barriers}

Cloudfunding is a web application that supports civic crowdfunding activities. Through the application, municipalities can support local communities to collect money for social and charitable purposes. The application can support the funding of various projects, i.e. related to the improvement of the urban environment, social entrepreneurship etc. The service is donation-based crowdfunding and has multiple benefits for a municipal authority since it raises public participation and brings flexibility in funding of small scale projects of urban regeneration (Gabison, 2015; Sedlitzky and Franz, 2019).

The service was designed in the context of EU's project STORM which aimed to address public authorities' need to shift to a cloud-based paradigm in service provisioning, mainly from the point of view of the end-users, and taking full advantage of edge ICT. The project provided a set of guidelines to public authorities and policymakers based on direct experimentation in many European cities, creating a set of relevant use cases and best practices. The project also delivered a consolidated cloudbased services portfolio validated by citizens and public authorities in four pilot cities (Valladolid, Thessaloniki, Agueda, Miskolc) and, at the same time, general and interoperable enough to be transferred and deployed in other cities. Following a Call for Cities, the experimentation of cloudification was carried out in three more cities: Athens, Veria, and Guimaraes.

The Cloudfunding application has been tested in the city of Thessaloniki to give Thessaloniki's citizens and organisations the ability to co-finance three types of projects: (a) projects for the improvement of the environment of the city (i.e. creation of parks and playgrounds, restoration of monuments, expansion of bike lanes, etc.), (b) projects for social entrepreneurship (i.e. creation of nonprofit enterprises to promote objectives that improve the city life or strengthen its social capital) and (c) projects for knowledge-intensive and technology-based youth entrepreneurship. In the first two categories, the municipality would act as a mediator of the whole funding and implementation process.

The main technologies used for the cloudification of the service were (a) OpenStack, the most popular and most adopted opensource, for the implementation of the IaaS Layer, (b) Cloud Foundry for the implementation of the PaaS Layer, since it had the best combination of usability, open-source community, and developer experience, (c) LAMP (Linux, Apache, MySQL and PHP) for the implementation of applications' Virtual Machines and (d) MySQL/MariaDB and PostgreSQL database engines for the implementation of Database Services Module.

Although it seems like a straightforward smart city application, its implementation posed significant legal and institutional barriers.

An initial set of challenges were confronted during the service development. The service was initially aimed to be developed over the open-source application CrowdTilt to be used as the 
Crowdfunding Platform. However, installing the application on the Linux platform was not sufficiently documented and was very difficult to achieve, but most significantly, it could not receive contributions/payments in Euro but only in US dollars through a payment processor company called "Balanced Payments". Altering the CrowdTilt source code so that another payment processor can manage payments in Euro could be a possible, yet, a difficult and lengthy process because of the way the application was written. Therefore, other similar open source solutions were reviewed (among which, Catarse, an open source crowdfunding platform for creative projects, and IgnitionDeck, a plugin for the WordPress platform, which transforms a WordPress installation into a full featured crowdfunding platform) and finally, Goteo was chosen, and a branch of it was developed for the city of Thessaloniki. Goteo is a web application that allows the receipt, review and publishing of collective campaigns for their collective funding through a crowdfunding process, as well as the dynamic visualization of the support received and classification of initiatives and campaign tracking.

The most difficult set of challenges however was related to payments given the legal and institutional framework of operation of the Municipality. First, was the ability to process payments without the use of an automated payment system that would temporarily withhold the money until the project on the crowdfunding platform succeeds (or not) its funding goal. The municipality cannot retain for limited time frame donations and, even more, return them in case the crowdfunding project does not achieve its goal. This problem could be solved using a payment processing company like Paypal, although there are significant constitutional limitations on behalf of the Municipality in creating and validating a Paypal account. The second was the ability to process a high volume of small scale transactions. The Municipality is legally allowed to receive money from donations, yet it has to provide receipts for each of these donations, no matter how small they are. This created a significant administrative burden to the administration which was already characterised by a low level of flexibility and a rigid organisational structure. Third, was the freedom to allocate municipal resources to a specific action that would be decided through the crowdfunding platform. Based on existing legislation, the financial resources of the Municipality are concentrated and an annual budget is being approved to be distributed in mostly predetermined services and activities. These rules are opposite to the Cloudfunding service's needs for short-term decision making on project acceptance and allocation of resources based on successful projects whose details are not known before.

These challenges, and many smaller ones, were magnified in the case of Thessaloniki Municipality which was stigmatised from economic management of the past and had to undergo a very strict monitoring process of all financial operations. As a response, it was proposed that the management of the Cloudfunding would be undertaken by the Metropolitan Development Agency of Thessaloniki, a non-profit development agency of the Municipality, which has greater flexibility and less strict rules for financial management and operations. Despite the efforts made, the service was never stated.

\section{Conclusion}

Smart city projects can address all challenges of cities, day-to-day usual problems or wicked problems and grand challenges of growth, poverty, sustainability, and safety. Projects may be deployed top-down in the framework of smart city strategies by public authorities, or bottom-up for the creation and offer of e-services by private organisations and companies. The review of the literature and the cases we analysed in the previous sections allow identifying three major driving conditions that shape smart city projects.

First, the ecosystem in which projects are placed: The city is a system of (eco)systems, and challenges, problems, stakeholders, and activities differ from one ecosystem to another. Ecosystems define the context and the dynamics of change. Smart city projects are organized by ecosystems, and usually many projects, independent or integrated, are necessary to change an ecosystem. Still, the smart city domain is very fragmented in vertical markets (energy, mobility, governance, real-estate) with little interoperability and exchange. Smart city projects follow this fragmentation, and the ecosystem of reference defines the know-how available and the potential for change.

Second, the connected intelligence mobilised by projects into the respective ecosystem: The Internet and digital technologies deployed by smart city projects may impact all types of intelligence. Human intelligence through learning and use of software that simplify complex methods and tasks, collective 
intelligence through online collaboration and crowdsourcing, and machine intelligence through data, analytics, AI, and prediction. These types of intelligence in combination, which we call connected intelligence, enable the realisation of the aims and impact of projects. Previous practices and experiments reveal various architectures of connectivity between digital and non-digital components of smart city projects, ranging from simple agglomeration of solutions over a common platform to orchestration of input-output and the flows between projects.

Third, the innovation introduced by smart city projects: Projects may produce (a) simple digitalisation, (b) digitalisation and optimisation, (c) digitalisation and innovation. In all cases, digitalisation is the baseline, and then optimisation or innovation or both can occur. Many projects just transfer activities from the physical to the digital space. Online transactions and e-commerce usually do this. This is the lowest level of innovation that can be achieved. In other cases, digitalisation, automation, and sharing lead to optimisation in the use of resources. Sensors and smart metering allow for saving energy and mobility. Sharing can optimise the deployment of effort, capital, and infrastructure. More complex, cyber-social-physical projects, integrating digital and non-digital technologies, can change radically the operation model of an ecosystem. Such radical changes affect sectors of the city economy with the development of platform-based ecosystems (hospitality, real estate, financial services), the city governance with forms of direct democracy, the mobility ecosystem with Mobility-as-a-Service (car sharing, carpooling, self-driving cars), the energy ecosystem with the deployment of distributed renewable energy.

The identification of these driving conditions suggests that major features of smart city projects are those of the ecosystem of reference, the substance of the project with its entities and architecture, and the impact with various degrees of city routines transformation. This allows for defining a typology of smart city projects by those three dimensions. The outcome is an "Intelligent City Cube" in which projects can be classified per three broad properties (1) ecosystem, (2) intelligence, and (3) innovation, and three alternative forms per property, as below:

- Ecosystem: (1.1) area-based

- Intelligence: (2.1) data-based

- Innovation: (3.1) digitalisation
(1.2) activity-based

(2.2) e-service-based

(3.2) optimisation
(1.3) network-based

(2.3) cyber-physical-social

(3.3) innovation

In the Intelligent City Cube (Fig. 2) 27 types of smart city projects can be defined, though some types are non-feasible, such as cyber-physical-social projects having as impact only digitalisation. Among the types, some combinations are most common in smart cities, such as "area-based ecosystem"+"cyber-physical-social entities"+"innovation" in smart districts; "activity-based ecosystem"+"e-service"+"innovation" in platform-based ecosystems; "network-based ecosystem"+"eservice"+"optimisation" in smart transport and smart utilities; "activity-based ecosystem" +"eservice"+"digitalisation" in smart marketplaces.

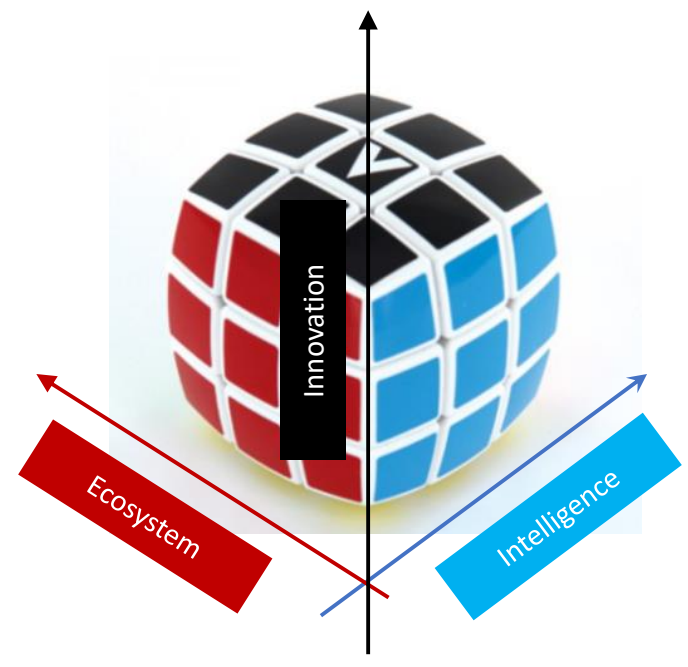

Figure 2: Intelligent City Cube classifying smart city projects 
Together with the above driving conditions, our analysis also revealed some major barriers to the success of smart city projects. Most barriers are organisational, legal, and institutional. This can be explained by the social and institutional inertial of the urban system against new solutions, especially when innovation and radical change of the existing operation routines take place. Change management should be a permanent companion of smart city projects implementation, and the modification of routines should be clearly defined and considered already at the design phase of the project.

\section{References}

Andrisano, O., Bartolini, I., Bellavista, P., Boeri, A., Bononi, L., Borghetti, A., ... \& Vigo, D. (2018). The need of multidisciplinary approaches and engineering tools for the development and implementation of the smart city paradigm. Proceedings of the IEEE, 106(4), 738-760.

Anthopoulos, L. (2019). Smart City Emergence: Cases from Around the World. Elsevier.

Arroub, A., Zahi, B., Sabir, E., \& Sadik, M. (2016, October). A literature review on Smart Cities: Paradigms, opportunities and open problems. In 2016 International conference on wireless networks and mobile communications (WINCOM) (pp. 180-186). IEEE.

Bosch, P., Jongeneel, S., Rovers, V., Neumann, H. M., Airaksinen, M., \& Huovila, A. (2017). CITYkeys indicators for smart city projects and smart cities. CITYkeys report.

Bosch, P., Jongeneel, S., Rovers, V., Neumann, H. M., Airaksinen, M., \& Huovila, A. (2017). CITYkeys indicators for smart city projects and smart cities. CITYkeys report.

Carmona, M., Burgess, R., \& Badenhorst, M. S. (2009). Planning through projects: Moving from master planning to strategic planning: 30 cities. Techne Press.

Chourabi, H., Nam, T., Walker, S., Gil-Garcia, J.R., Mellouli, S., Nahon, K., Pardo, T.A., Scholl, H.J. (2012). Understanding Smart City Initiatives: An Integrative and Comprehensive Theoretical Framework. In: Proceedings of the 45th Hawaii International Conference on System Sciences, pp. 2289-2297.

Cugurullo, F. (2018). Exposing smart cities and eco-cities: Frankenstein urbanism and the sustainability challenges of the experimental city. Environment and Planning A: Economy and Space, 50(1), 73-92.

Cugurullo, F. (2021). Frankenstein Urbanism: Eco, Smart and Autonomous Cities, Artificial Intelligence and the End of the City. Routledge.

Foth, M. (2017). The next urban paradigm: Cohabitation in the smart city. IT-Information Technology, 59(6), 259-262.

Frost \& Sullivan (2019). Smart Cities - Frost \& Sullivan Value Proposition. https://ww2.frost.com/wp-content/uploads/2019/01/SmartCities.pdf

Gabison, G. (2015) Understanding crowdfunding and its regulations: how can crowdfunding help ICT innovation? European Commission, JRC Science and Policy Report, doi:10.2791/562757

Gaffney, C., \& Robertson, C. (2018). Smarter than smart: Rio de Janeiro's flawed emergence as a smart city. Journal of Urban Technology, 25(3), 47-64.

Gates, S. (2002). Review of methodology of quantitative reviews using meta-analysis in ecology. Journal of Animal Ecology, 71(4), 547-557.

Caulier-Grice, J. (2016). What is Social Innovation? Social Innovator eXchange. http://www.socialinnovator.info/blog/social-innovator/what-social-innovation

Frenken, K., and Schor, J. (2019). Putting the sharing economy into perspective. In A research agenda for sustainable consumption governance. Edward Elgar Publishing.

Giffinger, R., \& Gudrun, H. (2010). Smart cities ranking: an effective instrument for the positioning of the cities? ACE: architecture, city and environment, 4(12), 7-26.

Giffinger, R., et al. (2007). Smart Cities-Ranking of European medium sized cities. Technical report. Centre of Regional Science at Vienna UT.

Greco, I., \& Bencardino, M. (2014, June). The paradigm of the modern city: SMART and SENSEable Cities for smart, inclusive and sustainable growth. In International Conference on Computational Science and Its Applications (pp. 579-597). Springer, Cham.

https://research.hva.nl/en/publications/organising-smart-city-projects-lessons-from-amsterdam 
IoT Analytics (2020). Smart City Use Cases \& Technology Report 2020. https://iotanalytics.com/product/smart-city-use-case-adoption-report-2020/

ITU-T FG-SCC (2015). Setting the framework for an ICT architecture of a smart sustainable city," Focus Group Technical Specifications. http://www.itu.int/en/ITUT/focusgroups/ssc/Documents/website/web-fg-ssc-0345-r5-ssc_architecture.docx

Kakderi, C., Komninos, N., and Tsarchopoulos, P. (2016). Smart cities and cloud computing: Lessons from the STORM CLOUDS experiment. Journal of Smart Cities, vol. 2, No 1, pp. 4-13.

Kogan, N., \& Lee, K. J. (2014). Exploratory research on the success factors and challenges of Smart City projects. Asia Pacific Journal of Information Systems, 24(2), 141-189.

Komninos, N. (2002). Intelligent cities: innovation, knowledge systems and digital spaces Routledge.

Komninos, N. (2014). The age of intelligent cities: smart environments and innovation-for-all strategies. Routledge.

Komninos, N. (2016). Intelligent cities and the evolution towards technology-enhanced, global, and user-driven territorial systems of innovation. In: D. Doloreux, R. Shearmur and C. Carrincazeaux (eds), Handbook on the Geography of Innovation, pp. 187-200, Edward Elgar.

Komninos, N. (2016). Smart environments and smart growth: Connecting innovation strategies and digital growth strategies. International Journal of Knowledge-Based Development, Vol.7, No.3, pp. $240-263$.

N. Komninos. (2018). Architectures of Intelligence in Smart Cities: Pathways to Problem-Solving and Innovation. ArchiDoct, 11, Vol. 6 (1), July.

Komninos, N. (2020). Smart Cities and Connected Intelligence: Platforms, ecosystems and network effects. Routledge.

Komninos, N., and Mora, L. (2018). Exploring the big picture of smart city research. Scienze Regionali, 17(1), 15-38.

Komninos, N., Kakderi, C., Panori, A. and Tsarchopoulos, P. (2018). Smart City Planning from an Evolutionary Perspective. Journal of Urban Technology, 26(2), 3-20.

Komninos, N., Panori, A., and Kakderi, C. (2020). The Smart City Ontology 2.0. URENIO Research Discussion Papers. Online https://www.urenio.org/2020/12/24/smart-city-ontology-2-0/

Kourtit, K., \& Nijkamp, P. (2012). Smart cities in the innovation age. Innovation: The European Journal of Social Science Research, 25(2), 93-95.

Kourtit, K., Nijkamp, P., \& Steenbruggen, J. (2017). The significance of digital data systems for smart city policy. Socio-Economic Planning Sciences, 58, 13-21.

Kulik, J. A., \& Kulik, C. L. C. (1989). Meta-Analysis in Education. International Journal of educational research, 13(3), 221-340.

Kunzmann, K. R. (2014). Smart cities: a new paradigm of urban development. Crios, 4(1), 9-20.

Monzon, A. (2015, May). Smart cities concept and challenges: Bases for the assessment of smart city projects. In 2015 international conference on smart cities and green ICT systems (SMARTGREENS) (pp. 1-11). IEEE.

Nieuwland, S., and Van Melik, R. (2020). Regulating Airbnb: how cities deal with perceived negative externalities of short-term rentals. Current Issues in Tourism, 23(7), 811-825.

Perboli, G., De Marco, A., Perfetti, F., \& Marone, M. (2014). A new taxonomy of smart city projects. Transportation Research Procedia, 3, 470-478.

Petrolo, R., Loscri, V., \& Mitton, N. (2017). Towards a smart city based on cloud of things, a survey on the smart city vision and paradigms. Transactions on Emerging Telecommunications Technologies, 28(1), e2931.

Rodrigues, N. and Costa, P. (2020). Urban experimentation and smart cities: a Foucauldian and autonomist approach. Territory, Politics, Governance, DOI: 10.1080/21622671.2020.1777896

Sedlitzky, R., \& Franz, Y. (2019). 'What If We All Chip In?'Civic Crowdfunding As Alternative Financing For Urban Development Projects. Built Environment, 45(1), 26-44

Stall-Meadows, C., \& Hyle, A. (2010). Procedural methodology for a grounded meta-analysis of qualitative case studies. International Journal of Consumer Studies, 34(4), 412-418.

Timulak, L. (2014). Qualitative meta-analysis. The SAGE handbook of qualitative data analysis, 481 . 
Tran Thi Hoang, G., Dupont, L., \& Camargo, M. (2019). Application of Decision-Making Methods in Smart City Projects: A Systematic Literature Review. Smart Cities, 2(3), 433-452.

Tsamboulatidis, I., Ververidis, D., Tsarchopoulos, P., Nikolopoulos, S. Kompatsiaris, I., and Komninos, N. (2013). ImproveMyCity - An open source platform for direct citizen-government communication. MM '13, Proceedings of the 21st ACM international conference on Multimedia, pp. 839-842.

Tsampoulatidis, I., Nikolopoulos, S., Kompatsiaris, I., and Komninos, N. (2020). Geographic citizen science in citizen-government communication and collaboration: Lessons learned from the Improve My City application. In: Geographic citizen science design: No one left behind, UCL Press, (186-205).

van Winden, W., Oskam, I., van den Buuse, D., Schrama, W., \& van Dijck, E. J. (2016). Organising smart city projects: Lessons from Amsterdam, Urban Economic Innovation, The Centre for Applied Research on Economics and Management (CAREM)

van Winden, W., Oskam, I., van den Buuse, D., Schrama, W., \& van Dijck, E. J. (2016). Organising smart city projects: Lessons from Amsterdam.

Wray, S. (2020). Public transport emerges as the top use of IoT in cities. Cities Today. https://cities-today.com/public-transport-emerges-as-the-top-use-of-iot-in-cities/

Yigitcanlar, T. (2016). Technology and the city: Systems, applications and implications. Routledge.

Yong Lee, J., and Chang, Ji-in (2019). The evolution of smart city policy in Korea. In: Smart City Emergence, pp. 173-194, Elsevier. 


\section{Appendix 1: Smart city projects by sector / ecosystem}

\begin{tabular}{|c|c|c|}
\hline City & $\begin{array}{l}\text { Sector / } \\
\text { ecosystem }\end{array}$ & Projects \\
\hline \multirow[t]{2}{*}{$\begin{array}{l}\text { Evora } \\
\text { (Portugal) } \\
\text { Smart City of Evora }\end{array}$} & Energy & $\begin{array}{l}\text { - Smart meters, smart homes } \\
\text { - Smart grid } \\
\text { - Public lighting } \\
\text { - EV charging } \\
\text { - Data collection \& modelling of energy system }\end{array}$ \\
\hline & Environment & $\begin{array}{l}\text { - Reduction of CO2 emissions } \\
\text { - } \text { Building retrofitting } \\
\text { - } \text { Solar thermal and solar PV } \\
\text { - Recycling } \\
\text { - Promotion of cycling } \\
\text { - Traffic restrictions } \\
\text { - } \text { Biofuel buses }\end{array}$ \\
\hline \multirow[t]{7}{*}{$\begin{array}{l}\text { Torino } \\
\text { (Italy) } \\
\text { Smart City of Torino }\end{array}$} & Mobility & $\begin{array}{l}\text { - } \text { Bike-sharing } \\
\text { - Plan bicycle path } \\
\text { - EV sharing } \\
\text { - Car-sharing service } \\
\text { - Car-pooling } \\
\text { - Traffic zone regulation (restriction) } \\
\text { - Traffic monitoring }\end{array}$ \\
\hline & Environment & $\begin{array}{ll}\text { - } & \text { District renewal } \\
\text { - } & \text { Smart squares } \\
\end{array}$ \\
\hline & $\begin{array}{l}\text { Startups, } \\
\text { innovation, skills }\end{array}$ & $\begin{array}{ll}\text { - } & \text { Social innovation / startup support } \\
\text { - } & \text { Youth employment } \\
\text { - } & \text { Support for public goods and services } \\
\end{array}$ \\
\hline & $\begin{array}{l}\text { Living, safety, } \\
\text { health }\end{array}$ & $\begin{array}{ll} & \text { Citizen awareness solutions } \\
\text { - } & \text { Safety solutions } \\
\text { - } & \text { Active aging } \\
\end{array}$ \\
\hline & Tourism & $\begin{array}{l}\text { - Information sharing } \\
\text { - Points of interest, city tourism } \\
\text { - Torino as a platform } \\
\end{array}$ \\
\hline & Governance & $\begin{array}{l}\text { - Health services from home } \\
\text { - Opening of public spaces to citizens } \\
\text { - Co-designing public services }\end{array}$ \\
\hline & Energy & $\begin{array}{l}\text { - Energy action plan: retrofitting, PV panels, RES, } \\
\text { LED } \\
\text { - IoT in schools for energy metering and saving }\end{array}$ \\
\hline \multirow[t]{5}{*}{$\begin{array}{l}\text { Leuven } \\
\text { (Belgium) } \\
\text { Smart City Leuven }\end{array}$} & $\begin{array}{l}\text { Mobility } \\
\text { (under } \\
\text { optimization of } \\
\text { streams) }\end{array}$ & $\begin{array}{l}\text { - Last mile delivery vehicles } \\
\text { - Semi-autonomous bus shuttle } \\
\text { - Bike-sharing } \\
\text { - Policing of shop and parking by sensors }\end{array}$ \\
\hline & $\begin{array}{l}\text { Energy } \\
\text { (under } \\
\text { optimization of } \\
\text { streams) }\end{array}$ & $\begin{array}{l}\text { - Smart city lights and sensor network } \\
\text { - Smart energy grid - interoperability } \\
\text { - Smart energy in building }\end{array}$ \\
\hline & Governance & $\begin{array}{l}\text { - Data platform for city administration } \\
\text { - Open data to share data with citizens and } \\
\text { entrepreneurs } \\
\text { - Digital Citizen: a digital profile of each citizen }\end{array}$ \\
\hline & Health & $\begin{array}{l}\text { - Living Lab for health(care) innovations } \\
\text { - E-Health site } \\
\text { - Vital City-innovative initiatives for active lifestyle } \\
\text { - Testing wearables to improve health }\end{array}$ \\
\hline & Education & - University student collaboration \\
\hline
\end{tabular}




\begin{tabular}{|c|c|c|}
\hline & & $\begin{array}{l}\text { - Working environment for knowledge workers } \\
\text { - Start-ups in residence }\end{array}$ \\
\hline \multirow[t]{5}{*}{$\begin{array}{l}\text { Vienna } \\
\text { (Austria) } \\
\text { Smart City of Vienna }\end{array}$} & Energy & $\begin{array}{l}\text { - ICT integration for buildings and electrical grid } \\
\text { Wien-Aspern (Grid, RES, and storage) } \\
\text { - Wien energy. Use of block-chain for transactions } \\
\text { - Clean heat, stable power grid. Excess electricity to } \\
\text { heat } \\
\text { - Energy monitoring and intelligent plant control in } \\
\text { Airport } \\
\text { - Urban Cool Down. Summer cooling in urban } \\
\text { districts }\end{array}$ \\
\hline & Education & $\begin{array}{l}\text { - Make your city smart: toolkit for do-it-yourself } \\
\text { building } \\
\text { - Vocational orientation of future jobs, robotics, apps, } \\
\text { RES } \\
\text { - Digital agenda Vienna. Interactive development of } \\
\text { ideas } \\
\text { - Digital city: ICT education }\end{array}$ \\
\hline & Governance & $\begin{array}{l}\text { - Sag's Wien application. Report to the city } \\
\text { administration } \\
\text { e-Government online services, registration, e- } \\
\text { signature }\end{array}$ \\
\hline & Mobility & $\begin{array}{l}\text { - Smart traffic lights } \\
\text { - Car sharing, e-cars } \\
\end{array}$ \\
\hline & District renewal & $\begin{array}{l}\text { - Renovation of former industrial sites, central } \\
\text { station, Danube bank, residential areas, and other }\end{array}$ \\
\hline \multirow{6}{*}{$\begin{array}{l}\text { Amsterdam } \\
\text { (The Nethedlands) } \\
\text { Amsterdam Smart City } \\
\text { (hundreds of initiatives at } \\
\text { https://amsterdamsmartcity.com/ } \\
\text { A few are included) }\end{array}$} & Digital city & $\begin{array}{l}\text { - IoT and sensors } \\
\text { - Digital infrastructure } \\
\text { - Promotion of various advanced technologies } \\
\text { (Blockchain, 5G, AI, Drones) }\end{array}$ \\
\hline & Energy & 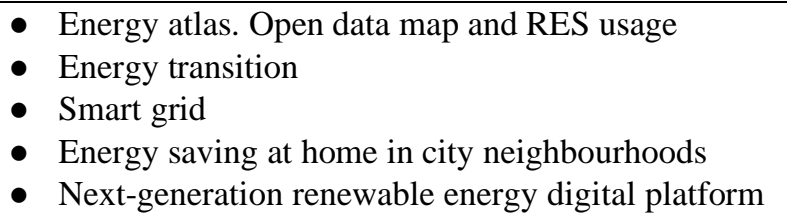 \\
\hline & Mobility & $\begin{array}{l}\text { - Mobility as a service } \\
\text { - City logistics } \\
\text { - Bicycle sharing } \\
\text { - Autonomous vehicles } \\
\text { - Crowd monitoring } \\
\text { - Electric vehicles }\end{array}$ \\
\hline & Circular city & $\begin{array}{l}\text { - } \text { Building and construction } \\
\text { - Public awareness } \\
\text { - e-Waste } \\
\text { - Make the circular economy and the upcycle visible } \\
\text { - Design-driven solutions to waste and consumerism } \\
\text { - New products from used pieces of plastics \& metal }\end{array}$ \\
\hline & $\begin{array}{l}\text { Governance and } \\
\text { education }\end{array}$ & $\begin{array}{l}\text { - Transition from smart to inclusive city } \\
\text { - Up-scaling } \\
\text { - Input-output modelling for smart city development }\end{array}$ \\
\hline & Citizen and living & $\begin{array}{l}\text { - Public participation } \\
\text { - Living labs } \\
\text { - Healthy urban living } \\
\text { - Sharing economy } \\
\text { - Social entrepreneurship } \\
\text { - Clean air monitoring }\end{array}$ \\
\hline Trikala & Mobility & - Smart parking and parking analytics \\
\hline
\end{tabular}




\begin{tabular}{|c|c|c|}
\hline \multirow[t]{6}{*}{$\begin{array}{l}\text { (Greece) } \\
\text { Smart City of Trikala }\end{array}$} & & $\begin{array}{l}\text { - Municipal fleet management } \\
\text { - Fleet analysis with vehicles position and routes } \\
\text { - Traffic lights monitoring for malfunction }\end{array}$ \\
\hline & Energy & - Smart lighting, upgrade to LED and motion sensors \\
\hline & Waste & - Smart bins with sensors installed \\
\hline & Water & - Smart water metering \\
\hline & Environment & - Sensor-based monitoring and metering \\
\hline & Governance & $\begin{array}{l}\text { - Public wi-fi } \\
\text { - End-to-end city management system } \\
\text { - } \text { GIS geospatial information } \\
\text { - Complaint registration and mobile app } \\
\text { - Public consultation } \\
\text { - } \text { Digital payments } \\
\end{array}$ \\
\hline \multirow{4}{*}{$\begin{array}{l}\text { Smart Cities in Korea } \\
\text { A common model for all } \\
\text { cities: } \\
\text { ICT based growth } \\
\text { ecosystems in cities }\end{array}$} & Governance & $\begin{array}{l}\text { - Gov with government agents } \\
\text { - } \text { Citizen cooperation } \\
\text { - } \quad \text { Public-private partnership } \\
\text { - Integrated policy legal system } \\
\end{array}$ \\
\hline & $\begin{array}{l}\text { Startups, } \\
\text { innovation, skills }\end{array}$ & $\begin{array}{l}\text { - Innovation led sustainable growth } \\
\text { - Innovative start-up } \\
\text { - Spaces for innovative job creation } \\
\text { - Clustering } \\
\text { - Spread of innovative ideas }\end{array}$ \\
\hline & Education & - Innovative education \\
\hline & $\begin{array}{l}\text { Mobility } \\
\text { Energy \& } \\
\text { Environment } \\
\text { Health } \\
\text { Safety } \\
\text { Welfare }\end{array}$ & $\begin{array}{l}\text { - ICT infrastructure } \\
\text { - Smart city technologies } \\
\text { - Integrated infrastructure with ICT } \\
\text { - Open data } \\
\text { - Big data } \\
\text { - Data sharing and integration } \\
\end{array}$ \\
\hline $\begin{array}{l}\text { Hangzhou } \\
\text { (China) } \\
\text { Dream Town Internet village }\end{array}$ & $\begin{array}{l}\text { Startups, } \\
\text { innovation, skills }\end{array}$ & $\begin{array}{l}\text { - Attraction of high-quality overseas talents in ICT, } \\
\text { biomedicine, RES, financial services } \\
\text { - Applications of e-business, software design, } \\
\text { information services, big data, security, animation } \\
\text { design } \\
\text { - Start-up support } \\
\text { - Start-up incubators and mentoring } \\
\text { - Grants: creative digital tickets (vouchers) } \\
\text { - Angel village, interaction with VC } \\
\text { - Collaboration and use of Alibaba infrastructure }\end{array}$ \\
\hline \multirow{6}{*}{$\begin{array}{l}\text { Changsha } \\
\text { (China) }\end{array}$} & Government & - e-Services for social insurance, taxation, police \\
\hline & Mobility & $\begin{array}{l}\text { - e-Services for information and ticketing } \\
\text { - Transport cloud for information, coordination, } \\
\text { service delivery }\end{array}$ \\
\hline & Commerce & - e-Services for shopping and online payment \\
\hline & Health & - e-Services in hospitals for medical service, payment \\
\hline & Tourism & - Hotel reservation, tourism venues, e-payment \\
\hline & Safety & $\begin{array}{l}\text { - } \text { Fire protection } \\
\text { - Police cloud big data platform } \\
\text { - } \quad \text { Police analytics and prediction } \\
\end{array}$ \\
\hline \multirow{4}{*}{ Smart City of Pune } & Energy & - Smart grid and solar panels \\
\hline & Water & - Smart metering \\
\hline & Mobility & $\begin{array}{l}\text { - } \text { e-Buses } \\
\text { - Electric Rickshaw / Electric Tuk-Tuk in Pune } \\
\text { - ICT-enabled bus } \\
\text { - Smart parking } \\
\text { - Adaptive traffic management }\end{array}$ \\
\hline & Safety & - CCTV \\
\hline
\end{tabular}




\begin{tabular}{|c|c|c|}
\hline & & - IT connectivity \\
\hline $\begin{array}{l}\text { Nara } \\
\text { (Japan) } \\
\text { Smart City of Nara }\end{array}$ & District renewal & $\begin{array}{l}\text { - Smart campus } \\
\text { - Smart housing district } \\
\text { - Smart grid and solar panel } \\
\text { - Solar thermal } \\
\text { - Energy management platform } \\
\text { - Data centre }\end{array}$ \\
\hline \multirow[t]{5}{*}{$\begin{array}{l}\text { Singapore } \\
\text { (Singapore) } \\
\text { Smart City of Singapore }\end{array}$} & Health & $\begin{array}{l}\text { - Elderly mobility using robotics } \\
\text { - App citizen wearables encouraging exercise } \\
\text { - Health monitoring at home } \\
\text { - Health related analytics }\end{array}$ \\
\hline & Living & $\begin{array}{l}\text { - App: User engagement on environmental issues } \\
\text { - App: Understand living conditions at home }\end{array}$ \\
\hline & Mobility & $\begin{array}{l}\text { - Access to public transportation } \\
\text { - } \text { Mobility analytics } \\
\text { - Smart parking } \\
\text { - Autonomous mobility testing }\end{array}$ \\
\hline & Government & $\begin{array}{l}\text { - Citizen database platform-interaction with gov. } \\
\text { - Access to numerous public services } \\
\text { - Open datasets } \\
\text { - Platform for sharing ideas } \\
\end{array}$ \\
\hline & $\begin{array}{l}\text { Startups, } \\
\text { innovation, skills }\end{array}$ & $\begin{array}{l}\text { - Financial database of business opportunities } \\
\text { - Digital transactions for citizens and businesses } \\
\text { - Digital training programs and fellowships } \\
\text { - Digital tools for innovative development } \\
\text { - Platforms for academic collaboration } \\
\text { - Business grants portal }\end{array}$ \\
\hline $\begin{array}{l}\text { Newark } \\
\text { (US) } \\
\text { Smart city of Newark }\end{array}$ & Government & $\begin{array}{l}\text { - Data analytics platform (B2B, B2C, open gov data, } \\
\text { crime, vacant lots, employment) } \\
\text { - Industrial analytics platform } \\
\text { - Smart city governance analytics }\end{array}$ \\
\hline $\begin{array}{l}\text { Quayside Toronto } \\
\text { (Canada) } \\
\text { Sidewalk Labs' Waterfront } \\
\text { Toronto } \\
\text { (before being abandoned) }\end{array}$ & District renewal & $\begin{array}{l}\text { - Self-driving shuttles } \\
\text { - Robot delivery } \\
\text { - Spaces showcasing new technologies } \\
\text { - Dynamic, reconfigurable pavement, allowing } \\
\text { different uses and activities throughout the day } \\
\text { - Building envelope technologies (raincoats) } \\
\text { - Responsible Data Use Framework }\end{array}$ \\
\hline \multirow[t]{2}{*}{$\begin{array}{l}\text { Porto Alegre } \\
\text { (Brazil) } \\
\text { Porto Alegre Smart City }\end{array}$} & Governance & $\begin{array}{l}\text { - Integrated command centre } \\
\text { - GIS data centre } \\
\text { - Bio-monitoring (trees, plant, pollutants) } \\
\text { - Training telecentres for literacy and digital } \\
\text { inclusion } \\
\text { - Smart city innovation centre }\end{array}$ \\
\hline & Health & $\begin{array}{l}\text { - Real-time monitoring of hospital bed occupation } \\
\text { - Sharing patient information } \\
\text { - Telemedicine, primary diagnoses }\end{array}$ \\
\hline \multirow{2}{*}{$\begin{array}{l}\text { Johannesburg } \\
\text { (South Africa) } \\
\text { Smart city of Johannesburg }\end{array}$} & Safety & $\begin{array}{l}\text { - Crime reporting application } \\
\text { - } 911 \text { response application } \\
\text { - Kitestring - check-up and emergency alert }\end{array}$ \\
\hline & Mobility & $\begin{array}{l}\text { - Intelligent Transport System } \\
\text { - Interactive application - real time transport }\end{array}$ \\
\hline \multirow[t]{2}{*}{$\begin{array}{l}\text { Tunis } \\
\text { (Tunisia) } \\
\text { Smart City of Tunis }\end{array}$} & $\begin{array}{l}\text { Startups, } \\
\text { innovation, skills }\end{array}$ & $\begin{array}{l}\text { - Digital entrepreneurship } \\
\text { - Digital innovation services } \\
\text { - Offshoring - place promotion } \\
\text { - IT promotion } \\
\end{array}$ \\
\hline & Governance & - Administrative services to citizens \\
\hline
\end{tabular}




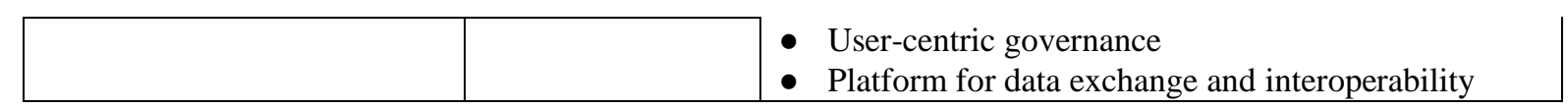

Source: Based on city reviews of the book

Anthopoulos (2021). Smart City Emergence: cases from around the world. Elsevier 